\title{
CHANGES OF PHYTOHORMONES CONTENT IN HALO- AND GLYCOPHYTES UNDER SALINITY
}

\author{
N. P. Vedenicheva', L. V. Voytenko', L. I. Musatenko', \\ L. A. Stetsenko ${ }^{2}$, N. I. Sevyakova ${ }^{2}$ \\ ${ }^{1}$ N. G. Kholodny Institute of Botany of the National Academy of Sciences of Ukraine \\ 2, Tereshchenkivska St., Kyiv 01601, Ukraine \\ e-mail: phytohormonology@ukr.net \\ ${ }^{2}$ K. A. Timiryazev Institute of Plant Physiology of Russian Academy of Sciences \\ 35, Botanicheskaya St., Moscow 127276, Russia \\ e-mail: larstet@mail.ru
}

Phytohormonal balance changes in plants with contrast salt resistance - glycophyte Phaseolus vulgaris L. and halophyte Mesembryanthemum crystallinum L. - under salt stress $(\mathrm{NaCl})$ were studied. It was assumed that salt tolerance of $M$. crystallinum is dependent on hormonal balance peculiarities, namely on, extremely low ABA level combined with high amount of IAA and cytokinins.

Key words: phytohormones, abscisic acid, indolyl-3-acetic acid, cytokinins, glycophytes, halophytes, stress, salinity, salt tolerance

\section{INTRODUCTION}

Over $6 \%$ of the world's land is affected by salinity and a proportion of salt-affected cultivated land arises every year as a result of irrigation. Investigation of salt tolerance mechanisms in plants is an urgent task because application of salt-resistant crop species is the way to use soils with high salt concentration in agriculture. Salts in the soil water may inhibit plant growth for two reasons. First, the presence of salt in the soil solution reduces the ability of the plant to take up water. This is referred as the osmotic or water-deficit effect of salinity. Second, if excessive amounts of salt enter the plant in the transpiration stream there will be damage to cells in the transpiring leaves and this may cause further reductions of growth. This is called as salt-specific or ion-excess effect of salinity [17]. The consequences of salinity are reduction of plant growth and enhancement of mature leaves senescence, resulting in a decrease in functional leaf area and, therefore, in crop yield. Thus, an increase of salt tolerance of crop plants allows greater yields in salt-affected soils. However, breeding of salt-tolerant crops is hampered by the complexity of salt tolerance as seen in halophytes [10]. One of the aspects of this problem is solving the question how salt resistance is regulated in plants. It is well known that plant reaction to stress is under hormonal control. The phytohormones ap- 
plied to plants were found to reduce the negative consequences of salinity for growth and development [11]. Treatment with plant growth substances enhanced salt tolerance of some crops $[5,18]$. Long-distance signaling from root to shoot under salinity was clamed to be mediated by ABA $[17,25]$. Recently it was shown that hormonal signals, such as cytokinins, ABA, ethylene, auxin, can regulate a source-sink relations during the osmotic phase of salinity (independent of specific ions) and affect whole-plant energy availability to prolong the maintenance of growth, root function and ion homeostasis, and could be critical to delay the accumulation of $\mathrm{Na}^{+}$or any other ion to toxic levels [19]. At the same time data about changes in endogenous phytohormones under salinity are contradictory and vary depending on the experiment conditions.

The aim of the present study was to compare qualitative and quantitative changes in the phytohormonal balance of plants with contrast salt resistance - glycophyte Phaseolus vulgaris L. and halophyte Mesembryanthemum crystallinum L. under $\mathrm{NaCl}$ influence.

\section{MATERIAL AND METHODS}

M. crystallinum seeds were germinated and seedlings were grown on nutrient solution as described earlier [16]. Adult plants (10 weeks old) were transferred to medium with $400 \mathrm{mM} \mathrm{NaCl}$. Mature leaves samples were gathered in 6, 24 and $48 \mathrm{~h}$, fixed by liquid nitrogen and stored at $-70^{\circ} \mathrm{C}$.

$P$. vulgaris (cultivar Belozernaja) seedlings were grown at the same conditions during 10 days. Salt stress was produced by the addition of $50,100,150$ and $200 \mathrm{mM} \mathrm{NaCl}$ to the nutrient medium. On $96 \mathrm{~h}$ of exposition on salt solution primary leaves and roots were fixed and stored (see above).

Endogenous phytohormones were extracted from samples after homogenization with $80 \%$ ethanol. After alcohol removal the water extract was frozen during $24 \mathrm{~h}$ and centrifuged at $15000 \mathrm{~g}$. IAA and ABA were extracted by diethylether at $\mathrm{pH} 3$. Cytokinins were extracted by butanol at $\mathrm{pH} 8$ and purified on Dowex $50 \mathrm{Wx} 8$ column. Extracts were purified by TLC chromatography. For stages of purification in detail see [4]. IAA, ABA and cytokinins amounts were measured by HPLC (Agilent 1200 LC, USA) using Eclipse XDB-C 18 column $(2,1 \times 150 \mathrm{~mm})$, particles size $5 \mu \mathrm{M}$. Elution was carried out with solvents system methanol:water (37:63).

Data were analyzed and processed by software Chem Station, version B.03.01 on line.

\section{RESULTS AND DISCUSSION}

Gradual decrease of $P$. vulgaris seedling biomass, primary leaves and roots sizes at $\mathrm{NaCl}$ concentrations from 50 to $150 \mathrm{mM}$ was accompanied by free ABA accumulation in these organs (Table 1). Conjugated ABA level decreased in roots and increased in leaves simultaneously. We assume that under salinity $A B A$ is synthesized in root both de novo and released from stored forms and transported to leaves where the excess of this hormone is inactivated by conjugation. This is confirmed by the data obtained on wheat where stress-induced ABA accumulation was connected with its biosynthesis in roots and movement in free form to ground organs [26]. Changes in free IAA level in roots in stress conditions were insignificant. Bound IAA level decreased twice as much

ISSN 1996-4536 • Біологічні Студії / Studia Biologica • 2011 • Том 5/№1 • С. 37-44 
at $50 \mathrm{mM} \mathrm{NaCl}$ and increased three times at concentration $100 \mathrm{mM} \mathrm{NaCl}$ (Table 1). Free and bound IAA content in leaves changed in the similar way: hormone concentration decreased in presence of $50 \mathrm{mM} \mathrm{NaCl}$ and increased 1.5-1.8 times at $100 \mathrm{mM}$. The same differential effect of various $\mathrm{NaCl}$ concentrations on cytokinins content was also observed. Zeatin, zeatin riboside and zeatin glucoside level in roots enhanced sharply tens times at $50 \mathrm{mM} \mathrm{NaCl}$, whereas at $100 \mathrm{mM} \mathrm{NaCl}$ - only 3 times as compared to control plants (Table 2). An opposite situation was observed in leaves: zeatin type cytokinins concentration decreased in presence of $50 \mathrm{mM} \mathrm{NaCl}$, but increased dramatically at $100 \mathrm{mM} \mathrm{NaCl}$ (Table 2). Changes in isopentenyladenosine levels in roots and leaves were similar to those of zeatin-type cytokinins. Salinity caused insignificant alteration in isopentenyladenine concentration.

Table 1

IAA and ABA content in Phaseolus vulgaris L. seedlings under $\mathrm{NaCl}$ salinity, $\mathrm{ng} / \mathrm{g}$ fresh plant weight

\begin{tabular}{c|c|c|c|c|c}
\hline \multirow{3}{*}{ Organ } & \multirow{2}{*}{$\mathrm{NaCl}, \mathrm{mM}$} & \multicolumn{2}{|c|}{ IAA } & \multicolumn{2}{c}{ ABA } \\
\cline { 2 - 6 } & & free & bound & free & bound \\
\hline \multirow{3}{*}{ Roots } & 0 & $14.0 \pm 0.6$ & $20.2 \pm 0.9$ & $1.6 \pm 0.1$ & $7.6 \pm 0.4$ \\
\cline { 2 - 6 } & 50 & $11.7 \pm 0.5$ & $9.8 \pm 0.4$ & $7.7 \pm 0.3$ & $3.9 \pm 0.2$ \\
\cline { 2 - 6 } & 100 & $12.8 \pm 0.5$ & $63.7 \pm 3.1$ & $35.5 \pm 1.6$ & $3.2 \pm 0.1$ \\
\hline \multirow{3}{*}{ Leaves } & 0 & $36.7 \pm 1.7$ & $32.2 \pm 1.6$ & $2.0 \pm 0.1$ & $5.7 \pm 0.3$ \\
\cline { 2 - 6 } & 50 & $10.0 \pm 0.05$ & $22.6 \pm 1.0$ & $1.9 \pm 0.1$ & $7.4 \pm 0.3$ \\
\cline { 2 - 6 } & 100 & $52.8 \pm 2.5$ & $59.0 \pm 3.0$ & $8.2 \pm 0.3$ & $31.2 \pm 1.4$ \\
\hline
\end{tabular}

Table 2

Cytokinins content in Phaseolus vulgaris L. seedlings under $\mathrm{NaCl}$ salinity, $\mathrm{ng} / \mathrm{g}$ fresh plant weight

\begin{tabular}{c|c|c|c|c|c|c}
\hline \multirow{2}{*}{ Organ } & $\mathrm{NaCl}, \mathrm{mM}$ & $\begin{array}{c}\text { Zeatin } \\
\text { glucoside }\end{array}$ & Zeatin & $\begin{array}{c}\text { Zeatin } \\
\text { riboside }\end{array}$ & $\begin{array}{c}\text { Isopentenyl- } \\
\text { adenine }\end{array}$ & $\begin{array}{c}\text { Isopentenyl- } \\
\text { adenosine }\end{array}$ \\
\hline \multirow{4}{*}{ Roots } & 0 & $8.0 \pm 0.3$ & $4.8 \pm 0.2$ & $158.8 \pm 4.7$ & $22.1 \pm 0.9$ & $15.8 \pm 0.7$ \\
\cline { 2 - 7 } & 50 & $103.5 \pm 4.8$ & $148.8 \pm 6.2$ & $195.0 \pm 8.7$ & $36.5 \pm 1.3$ & $294.7 \pm 13.2$ \\
\cline { 2 - 7 } & 100 & $11.6 \pm 0.4$ & $12.0 \pm 0.5$ & $131.3 \pm 5.4$ & $34.9 \pm 1.2$ & $261.5 \pm 11.1$ \\
\hline \multirow{3}{*}{ Leaves } & 0 & $2.2 \pm 0.1$ & $28.2 \pm 1.3$ & $102.3 \pm 4.7$ & $15.7 \pm 0.6$ & $100.0 \pm 4.3$ \\
\cline { 2 - 7 } & 50 & $0.8 \pm 0.03$ & $5.5 \pm 0.2$ & $39.2 \pm 1.8$ & $4.7 \pm 0.1$ & $9.2 \pm 0.4$ \\
\cline { 2 - 7 } & 100 & $83.4 \pm 3.7$ & $207.4 \pm 7.8$ & $105.4 \pm 4.8$ & $18.8 \pm 0.8$ & $256.6 \pm 10.3$ \\
\hline
\end{tabular}

M. crystallinum control plants leaves contained relatively high concentrations of zeatin, isopentenyladenosine and free IAA. At the same time, zeatin riboside, isopentenyladenine and $A B A$ levels were extremely low, approximated to the method sensitivity 
limit (Table 3, 4). Seedlings growing on the nutrient solution with $400 \mathrm{mM} \mathrm{NaCl}$ during $6 \mathrm{~h}$ resulted in some rising of zeatin and bound IAA contents (about 1,5 times). Isopentenyladenosine and free IAA levels dropped sharply while zeatin riboside, isopentenyladenine and ABA increased dramatically. Further plants retention in the hypersaline solution created a gradual accumulation of zeatin riboside, isopentenyladenine, isopentenyladenosine and conjugated IAA in leaves (Table 3, 4). Content of conjugated cytokinin - zeatin glucoside - was insignificant and it was shown to decrease during first $24 \mathrm{~h}$ but then return to initial level (Table 4). It should be noted that both free and bound ABA levels in control plants leaves were very low. ABA accumulation took place under salinity, but on $48 \mathrm{~h}$ its content decreased again.

Table 3

IAA and ABA content in Mesembryanthemum crystallinum L. leaves under $\mathrm{NaCl}$ salinity $(400 \mathrm{mM}), \mathrm{ng} / \mathrm{g}$ fresh plant weight

\begin{tabular}{c|c|c|c|c}
\hline \multirow{2}{*}{ Time, h } & \multicolumn{2}{|c|}{ IAA } & \multicolumn{2}{c}{ ABA } \\
\cline { 2 - 5 } & free & bound & free & bound \\
\hline Control & $66.0 \pm 2.3$ & $8.9 \pm 0.2$ & $0.2 \pm 0.01$ & traces \\
\hline 6 & $9.3 \pm 0.4$ & $11.2 \pm 0.5$ & $1.8 \pm 0.06$ & $7.4 \pm 0.2$ \\
\hline 24 & $14.4 \pm 0.6$ & $1.0 \pm 0.07$ & $4.5 \pm 0.1$ & traces \\
\hline 48 & $6.8 \pm 0.2$ & $35.1 \pm 1.0$ & $1.0 \pm 0.05$ & $2.3 \pm 0.06$ \\
\hline
\end{tabular}

Table 4

Cytokinins content in Mesembryanthemum crystallinum L. leaves under $\mathrm{NaCl}$ salinity $(400 \mathrm{mM}), \mathrm{ng} / \mathrm{g}$ fresh plant weight

\begin{tabular}{c|c|c|c|c|c}
\hline Time, h & $\begin{array}{c}\text { Zeatin } \\
\text { glucoside }\end{array}$ & Zeatin & $\begin{array}{c}\text { Zeatin } \\
\text { riboside }\end{array}$ & $\begin{array}{c}\text { Isopentenyl- } \\
\text { adenine }\end{array}$ & $\begin{array}{c}\text { Isopentenyl- } \\
\text { adenosine }\end{array}$ \\
\hline Control & $8.1 \pm 0.3$ & $47.1 \pm 2.3$ & traces & $0.4 \pm 0.02$ & $72.4 \pm 3.4$ \\
\hline 6 & $3.5 \pm 0.1$ & $65.0 \pm 3.1$ & $23.1 \pm 1.2$ & $28.7 \pm 1.2$ & $0.7 \pm 0.04$ \\
\hline 24 & $2.9 \pm 0.09$ & $62.3 \pm 3.1$ & $108.8 \pm 5.1$ & $47.4 \pm 2.2$ & $14.0 \pm 0.5$ \\
\hline 48 & $10.7 \pm 0.4$ & $89.6 \pm 4.3$ & $197.7 \pm 9.7$ & $12.2 \pm 0.3$ & $15.6 \pm 0.7$ \\
\hline
\end{tabular}

The previous investigations of salinity effects on endogenous phytohormones have been done mainly on glycophytes and obtained results varied depending on experiments conditions. Thus, IAA content decreased extremely in salinized tomato [7] and iris [24], whereas in wheat leaves [1] and maize roots [3] under the influence of $\mathrm{NaCl}$ IAA accumulation occurred. It appears that when interpreting the experiment results the salt concentration, experiment duration and plant tissue type should be considered [1]. Information about cytokinins dynamics under salinity is limited. Decrease of cytokinins total amount in response to stress was shown [12]. However, the degree of changes in the concentration of specific cytokinin forms was different. For example, $\mathrm{NaCl}$

ISSN 1996-4536 • Біологічні Студії / Studia Biologica • 2011 • Том 5/№1 • С. 37-44 
solution induced significant increase in zeatin riboside content in maize roots [3]. In salinized tomato leaves, on the background of the total cytokinin concentration decrease, the level of zeatin riboside reduced most significantly [7]. Isopentenyl-type cytokinins content increment was stimulated by $\mathrm{NaCl}$ in pea plants [8]. ABA production in plant tissues under salt stress was shown by many authors [2, 20, 24]. ABA accumulation was shown for stomata cells and mesophyll of barley leaves on 10 min after plant transition into $\mathrm{NaCl}$ solution but it was absent in vascular bundles [1] and this fact is contradictory to the previous assumption that ABA is transported from roots to shoots under salinity [13]. Unfortunately, the exact role of ABA both in salt stress signaling and salt tolerance is unknown.

In general, it might be concluded on the basis of our experiments and literature data that a decline of all growth characteristics in glycophytic plants under salinity is regulated by essential changes in the phytohormonal balance.

As regards halophytes the data about reaction of their hormonal system on salinity are very limited [14]. Some information is available about ice common plant (M. crystallinum) which is facultative halophyte and grows on soils with broad range of salinity [6]. $M$. crystallinum has an ability to change the photosynthesis type from $\mathrm{C}_{3}$ to more effective CAM under salt stress. The previous study revealed an acceleration of those plants transition to CAM metabolism after roots and leaves pretreatment with exogenous ABA [9]. Addition of $10^{-5} \mathrm{M}$ ABA together with $\mathrm{NaCl}$ to nutrient medium induced CAM-type photosynthesis and enhanced stress tolerance in $M$. crystallinum growing in water culture [13]. ABA treatment caused a $10 \%$ transpiration reduction in $M$. crystallinum and thus, decreased water loss and prevented negative influence of osmotic stress during salinity [15]. As revealed from our experiments, a specific feature of $M$. crystallinum was an extremely low leaf ABA content as well as an insignificant in its absolute value, but significant in comparison with the control, fluctuation of this hormone amount in the plants affected by $\mathrm{NaCl}$. Whereas, glycophytes were characterized by more sufficient increase in ABA level as a response to stress. Similar results were obtained earlier [23]. This contradicts to general opinion about ABA primary role in salt tolerance [2], but it is this specificity of the hormonal balance that probably forms the salt resistance of $M$. crystallinum.

The comparison of the ABA and cytokinins quantitative relations demonstrated an essential domination of the latter. It was previously shown by radioimmunoassay that total cytokinins amount in ice common plants under salinity almost did not change [22]. However, the application of the more precise method in our experiments revealed differential changes in cytokinin-type hormones. It may be suggested that the key role in the signal mediation during salinity is played by only one of them, while others are involved in the cytokinin metabolic cycle but the confirmation of this suggestion requires more detail studies. Exogenous treatment of $M$. crystallinum with 6-BAP solution was shown to inhibit the activity of CAM-metabolism key enzyme - phosphoenolpyruvate carboxylase - and plants transition to CAM-metabolism under salt stress [21]. That is why the increase of zeatin, zeatin riboside and isopentenyladenine levels observed in our investigation may be considered as a mechanism preventing the metabolism type changes under salinity. BAP addition to nutrient solution in hydroponic culture of $M$. crystallinum resulted in the same quantitative phosphoenolpyruvate carboxylase increase as the $\mathrm{NaCl}$ addition [23]. This fact indicates that cytokinins are most probably involved in the multicomponent system that mediated $M$. crystallinum metabolic transformations under salinity. 


\section{CONCLUSION}

Thus, investigation of changes in the phytohormones dynamics have shown their obvious participation in signaling pathways of both glycophytic and halophytic plants during salt stress. The attribute of the high salinity resistant plant ( $M$. crystallinum) hormonal balance was a very low absolute ABA content comparing with IAA and cytokinins. Different patterns of specific cytokinins changes indicated that they play a differential role in $M$. crystallinum salt tolerance maintenance.

\section{ACKNOWLEDGEMENTS}

This work was partially supported by the National Academy of Sciences of Ukraine (№ 03-04-10) and Russian Foundation for Basic Research (№ 10-04-90417-Ukr) "Hormonal regulation of polyamine biosynthesis under stresses".

1. Ахиярова Г.Р., Сабиржанова И.Б., Веселов Д.С., Фрике В. Участие гормонов в возобновлении роста побегов пшеницы при кратковременном засолении $\mathrm{NaCl}$. Физиология растений, 2005; 52(6): 891-896.

2. Веселов Д.С., Маркова И.В., Кудоярова Г.Р. Реакция растений на засоление и формирование солеустойчивости. Успехи современной биологии, 2007; 127 (5): 482-493.

3. Калинина Н.А., Драговоз И.В., Яворская В.К. Фитогормональный баланс корней кукурузы на фоне действия хлоридного засоления и 6-БАП. Ученые записки Таврического национального университета им. В.И. Вернадского, 2001; 14(53), ч. 1: 84-87.

4. Мусатенко Л.И., Веденичева Н.П., Васюк В.А. и др. Комплекс фитогормонов в проростках различных по устойчивости к повышенным температурам гибридов кукурузы. Физиология растений, 2003; 50(4): 499-504.

5. Титов А.Ф., Таланова В.В. Устойчивость растений и фитогормоны. Петрозаводск: Карельский научный центр РАН, 2009. 206 с.

6. Adams P., Nelson D.E., Yamada S. et al. Growth and development of Mesembryanthemum crystallinum (Aizoaceae). New Phytologist, 1998; 138(2): 171-190.

7. Albacete A., Ghanem M.E., Martínez-Andújar C. et al. Hormonal changes in relation to biomass partitioning and shoot growth impairment in salinized tomato (Solanum lycopersicum L.) plants. J. Exp. Bot, 2008; 59(15): 4119-4131.

8. Atanasova L., Pissurska M., Stoyanov I. Cytokinins and growth responses of maize and pea plants to salt stress. Bulg. J. Plant Physiol, 1996; 22(1-2): 22-31.

9. Chu C., Dai Z., Ku S.B.M., Edwards G.E. Induction of Crassulacean Acid Metabolism in the facultative halophyte Mesembryanthemum crystallinum L. by abscisic acid. Plant Physiol, 1990; 93: 1253-1260.

10. Flowers T.J., Galal H.K., Bromham L. Evolution of halophytes: multiple origins of salt tolerance in land plants. Functional Plant Biology, 2010; 37(7): 604-612.

11. Gurmani A. R., Bano A., Din J. et al. Effect of phytohormones on growth and ion accumulation of wheat under salinity stress. African Journal of Biotechnology, 2009; 8(9): 18871894.

12. Hussein M.M., Nadia H., EL-Gereadly M., EL-Desuki M. Role of putrescine in resistance to salinity of pea plants (Pisum sativum L.). J. Applied Science Research, 2006; 2(9): 598604.

13. Kefu Z., Munns R., King R.W. Abscisic acid levels in NaCl-treated barley, cotton and saltbush. Aust. J. Plant Physiol, 1991; 18(1): 17-24.

14. Ksouri R., Megdiche W., Koyro H.-W., Abdelly C. Responses of halophytes to environmental stresses with special emphasis to salinity. Advances in Botanical Research, 2010; 53: $117-145$

ISSN 1996-4536 • Біологічні Студії / Studia Biologica • 2011 • Том 5/№1 • С. 37-44 
15. Kuznetsov VI.V., Kruglova A.G., Molodyuk O.I. et al. Hormonal regulation of crassulacean acid metabolism (CAM) and inter-organ stress signal transduction. Phytohormones in Plant Biotechnology and Agriculture. Netherlands: Kluver Academic Publishers, 2003: 195-203.

16. Kuznetsov VI.V., Stetsenko L.A., Shevyakova N.I. Exogenous cadaverine induces oxidative burst and reduces cadaverine conjugate content in the common ice plant. J. Plant Physiol, 2009; 166 (1): 40-51.

17. Munns R., Tester M. Mechanisms of salinity tolerance. Ann. Rev. Plant Biology, 2008; 59(1): 651-681.

18. Nandini-Chakrabarti S., Mukherji N., Chakrabarti N. Effect of phytohormone pretreatment on metabolic changes in Vigna radiata under salt stress. J. Environmental Biology, 2002; 23: 295-300.

19. Pérez-Alfocea F., Albacete A., Ghanem M.E., Dodd I.C. Hormonal regulation of source-sink relations to maintain crop productivity under salinity: a case study of root-to-shoot signalling in tomato. Functional Plant Biology, 2010; 37(7): 592-603.

20. Shakirova F.M., Sakhabutdinova M.V., Farkhutdinova R.A., Farkhutdinova D.R. Changes in the hormonal status of wheat seedlings induced by salicylic acid and salinity. Plant Sciences, 2003; 164 (3): 317-322.

21. Schmitt J.M., Piepenbrock M. Regulation of phosphoenolpyruvate carboxylase and crassulacean acid metabolism induction in Mesembryantheum crystallinum L. by cytokinins. Plant Physiol, 1992; 99: 1664-1669.

22. Thomas J.C., McElwain E.F., Bohnert H.J. Convergent induction of osmotic stress-responses. Plant Physiol, 1992; 100(2): P. 416-423.

23. Thomas J.C., Bohnert H.J. Salt stress perception and plant growth regulators in the halophyte Mesembryanthemum crystallinum. Plant Physiol, 1993; 103: 1299-1304.

24. Yongyin W., Mopper S., Hasenstein K.H. Effects of salinity on endogenous ABA, IAA, JA and SA in Iris hexagona. J. Chem. Ecol, 2001; 27(2): 327-342.

25. Zhang J., Jia W., Yang J., Ismail A.M. Role of ABA in integrating plant responses to drought and salt stresses. Field Crops Research, 2006; 97(1): 111-119.

26. Zhao Z., Chen G., Zhang $C$. Interaction between reactive oxygen species and nitric oxide in drought-induced abscisic acid synthesis in root tips of wheat seedlings. Australian J. Plant Physiol, 2001; 28: 1055-1061.

\title{
ЗМІНИ ФІТОГОРМОНАЛЬНОГО БАЛАНСУ У ГЛІКО- І ГАЛОФІТІВ ПРИ ЗАСОЛЕННІ
}

\author{
Н. П. Веденичова ${ }^{1}$, Л. В. Войтенко ${ }^{1}$, Л. І. Мусатенко ${ }^{1}$, \\ Л. О. Стеценко ${ }^{2}$, Н. І. Шевякова ${ }^{2}$ \\ ${ }^{1} /$ нститут ботаніки ім. М.Г. Холодного НАН України \\ вул. Терещенківська, 2, Київ 01601, Україна \\ e-mail: phytohormonology@ukr.net \\ ${ }^{2}$ /нститут фозіології рослин ім. К.А. Тімірязєва РАН \\ вул. Ботанічна, 35, Москва 127276, Росія \\ e-mail: larstet@mail.ru
}

Досліджено зміни фрітогормонального балансу у рослин з контрастною солестійкістю - глікофіта Phaseolus vulgaris L. і галофіта Mesembryanthemum crystallinum L. - за дії сольового стресу ( $\mathrm{NaCl}$ ). Зроблено припущення, що солестійкість M. crystallinum пов'язана з особливостями гормонального балансу, а саме із вкрай низьким вмістом АБК на фоні суттєвих кількостей ІОК і цитокінінів. 
Ключові слова: фрітогормони, абсцизова кислота, індолілоцтова кислота, цитокініни, глікофіти, галофіти, стрес, засолення, солестійкість.

\section{ИЗМЕНЕНИЯ ФИТОГОРМОНАЛЬНОГО БАЛАНСА У ГЛИКО- И ГАЛОФИТОВ ПРИ ЗАСОЛЕНИИ}

Н. П. Веденичева ${ }^{1}$, Л. В. Войтенко ${ }^{1}$ Л. И. Мусатенко Л. А. Стеценко ${ }^{2}$, Н. И. Шевякова

${ }^{1}$ Институт ботаники им. Н.Г. Холодного НАН Украины ул. Терещенковская, 2, Киев 01601, Украина e-mail: phytohormonology@ukr.net

${ }^{2}$ Институт фризиологии растений им. К.А. Тимирязева РАН ул. Ботаническая, 35, Москва 127276, Россия e-mail: larstet@mail.ru

Изучены изменения фитогормонального баланса у растений с контрастной солеустойчивостью - гликофита Phaseolus vulgaris L. и галофита Mesembryanthemum crystallinum L. - под влиянием солевого стресса ( $\mathrm{NaCl})$. Высказано предположение, что солеустойчивость M. crystallinum связана с особенностями гормонального баланса, а именно с крайне низким содержанием АБК на фоне существенных количеств ИУК и цитокининов.

Ключевые слова: фитогормоны, абсцизовая кислота, цитокинины, индолилуксусная кислота, гликофиты, галофиты, стресс, засоление, солеустойчивость.

Одержано: 13.03.2011 